\title{
Trends and Regulatory Challenges of Environmental Institutions: Evidences from Federal and selected Regions of Ethiopia
}

\author{
Alemayehu Assefa Assele (Corresponding author) \\ Addis Ababa University, College of Development Studies \\ Center for Environment and Development, P.O.B 1176, Addis Ababa, Ethiopia \\ E-mail: alemayehu.assefa@aau.edu.et \\ Yohannes Aberra $(\mathrm{PhD})$ Associate professor \\ College of Development studies, Center for environment and Development \\ Addis Ababa University, P.O.B 1176, Addis Ababa, Ethiopia \\ E-mail: yohaba2021@gmail.com \\ Dawit Diriba (PhD), Assistant professor \\ College of Development Studies, Center for Environment and Development \\ Addis Ababa University, P.O.B 1176, Addis Ababa, Ethiopia \\ E-mail: davdiriba@yahoo.com
}

Received: February 14, 2019 Accepted: March 6, 2019 Published: April 3, 2019

doi:10.5296/emsd.v8i2.14603

URL: https://doi.org/10.5296/emsd.v8i2.14603

\begin{abstract}
The trend of development of environmental institutions in the third world has experienced a considerable lag since 1970s compared to the pace and scale of environmental threats; and mainly challenged by poor autonomy, weak regulatory capacity, and inadequate political support. Ethiopia, being prone to recurrent droughts and environmental maladies, has been grappled with policy responses towards building green and environmentally benign economy. The objective of this study was to explore the trends of institutionalization in environment sector and the challenges that hamper their regulatory performances in Ethiopia. Based on
\end{abstract}


evidences from federal to local levels, the study has indicated that Ethiopia has made its late debut in institutionalization of environmental mandates in early 1990s and introduced three waves of institutional reforms so far. The institutionalization process both at the center and regional levels has got some arduous challenges, most of which were akin to the experiences of other developing countries. However, there were some distinct challenges in Ethiopian context such as sustained influence from agriculture sector coupled with parochialism in mandate allocation, recurrence of droughts that mostly caught the wits of policy makers, and resource laden economic growth which utterly undermined environmental regulations. Therefore, redefining institutional mandates to avoid role conflict, elevating their status and autonomy, and working towards filling the environmental knowledge deficit could be amicable solutions.

Keywords: Ethiopia, Environmental governance, Institutions

\section{Introduction}

Sound management of natural environment has increasingly become a lynchpin of economies around the world for poverty reduction, sustainable development and ensuring harmony between the social and natural system, the pursuit of which calls for formulation of environmental policies and erection of strong regulatory institutions (Organization for Economic Co-operation and Development [OECD], 2012). In the wake of increasing anthropogenic effects on environment, there is quite a growing consensus that effective governance can have a remedial effect in curbing the problem (Evans, 2012). As studies indicate, one of the areas that strongly called for the new governance agenda at theory and policy quarters, among others, is the issue of global and local environmental crisis (Bevir, 2010; Gisselquist, 2012). Even though the effects of human actions on natural environment have been widely felt since industrialization, concerted efforts through policy formulation and institutionalization of environmental mandates are only of the recent past (Ravnborg, 2013). Despite early efforts of wilderness and nature conservation movements at the aftermath of industrial revolution (Evans, 2012), the trend of environmental policy making and erection of regulatory institutions in response to environmental threats has vividly appeared at global stage since early 1970s (Jordan, 2005; Ravnborg, 2013) with the conduct of the Stockholm conference, which brought in to effect the first international environmental institution, i.e., the United Nations Environmental Program (UNEP) (Jordan, 2005). Since then, environmental governance has become a centerpiece of national and regional policies and ascended a new height over the last few decades (Evans, 2012; OECD, 2012). Hence, formulation of environmental policies was guided by a new insight that took into account the complex, transboundary, and dynamic nature of environmental problems which brought forth the necessity of globalized institutional response, on one hand and localized actions, on the other hand (Park et al., 2008). With the formation of UNEP, erection of national environmental ministries was marshaled around Europe and other developing countries (Jordan, 2005). However, evidences indicate that the trends of institutional response across the developing world since the Stockholm conference have been slow compared to the scope and severity of the problem being posed by the on-going environmental crisis (Bosselmann, Engel \& Taylor, 2008). 
On top of the lag in trends of policy and institutionalization, there were arduous challenges that environmental institutions have been facing in relation to discharging their regulatory roles. In this regard, there is a growing body of literature that suggests institutional weaknesses to be accountable for the usual blame of 'doing little' to curb the bigger problem of the globe (Evans, 2012; Barrow, 2005). A review of case studies and official reports across Europe, Latin America, China and Africa have indicated that environmental regulatory institutions fall short of properly discharging their mandates due to weak internal capacities, low political support, inadequate resource provision, poor understanding of the complex and dynamic nature of environmental problems, poor devolution of power to the lower levels, and lack of cross-sectoral coordination (Rossow \& Wiseman, 2004; Mruma, 2005; United Nations Economic Commission for Europe [UNECE], 2007; Berkes, 2010, Ministry of Environment, water and Natural Resources of Kenya, 2013). Most of the country case studies in eastern Europe further indicated that environmental ministries face unnecessary amalgamation with non-environmental functions and hence their regulatory roles have often been undermined (UNECE, 2007). According to the World Bank report (2008), third world countries have a low record of institutional performance particularly in areas such as adequacy of prioritization, quality of environmental assessment, cross-sectoral coordination, and public information and participation (World Bank, 2008). Moreover, in a situation where the jolt of extreme poverty pushes government plans to be heavily lop-sided towards economic generation, developing country governments often fail to make the necessary balance between economic progress and environmental protection and thus the regulatory role of environmental institutions is often compromised (UNECE, 2007).With this tendency, the role of environmental institutions has often been disregarded, bypassed, and environmental priorities are poorly mainstreamed in to the overall socio economic planning at macro and micro levels(Swedish Environmental Protection Agency[SEPA], 2012).

Ethiopia, being grappled with the issues of curbing economic poverty and environmental degradation, is in a defining juncture towards embracing sustainable development through greening its economy (Environmental Protection Agency of Ethiopia [EPA], 2012; Ministry of Finance and Economic Development of Ethiopia [MoFED], 2014). Even though the country entered the arena of environmental governance through undertaking policy and institutional measures in early 1990s, the trend of its performance has multiple facets that range from worse record of environmental negligence (Kruger et al., 2013) to a noteworthy policy commitment towards building a climate resilient green economy (MoFED, 2014). Despite its prominence being signatory to several multilateral environmental agreements and active agent at the global platforms of climate politics, Ethiopia's overall environmental records are abysmal (Hsu et al., 2016). Similar to other poor countries, economic development heavily gravitates the attention of policy makers and implementers alike (Kruger et al., 2013). The policy implementation in general and regulatory performance of environmental institutions in particular has been problematic (Damtie, 2010) whereas there are scant studies that could inform policy makers and practitioners to help ameliorate this situation. Even though there has been notable attempt of institutional development over the past two decades, internal capacity limitations, role confusion and instability resulting in poor enforcement of environmental laws typified by lack of consistency and predictability have 
been characteristic features of environmental institutions in Ethiopia (Ruffies et al., 2010; Janka, 2014; Mulugeta, 2012; Cesar \& Anders, 2013).

\section{Objectives of the Study}

This study was meant to achieve three major objectives. First, it provides a brief overview of the recent trends of institutional development in environment sector of Ethiopia. Second, it analyses the regulatory performances of environmental institutions and challenges they face in relation to discharging their responsibilities. Third, it unveils the underlying causes of these challenges in order to inform policy makers for improved decisions towards effective environmental governance in Ethiopia.

\section{Methodology}

\subsection{Description of Study Areas}

Ethiopia is located in the horn of Africa extending from 3-15 degrees North latitude and 33-48 degrees East longitude covering a total area of 1.1 million $\mathrm{km}^{2}$ (Central Statistics Authority [CSA], 2007). It is the most populous country in the horn of Africa with a recent estimation of over 105 million population growing at a rate of $2.9 \%$ per annum (Central Intelligence Agency, 2018). 65\% of its agro-ecology being highland, sizeable portion of its land area lies above $3000 \mathrm{~m}$ (Birhanu, 2014).

Traditionally, the highlands are preferred for human settlement and sedentary livelihood, which caused severe soil and vegetation degradation (Hurni et al., 2010; Zeleke, 2010). Hence, the relationship between the natural environment and population distribution has been characterized by an intensifying degradation of soil, water and vegetation (Zeleke, 2010). Politically, Ethiopia is a federal state comprising nine autonomous Regional States and two city administrations (FDRE, 1995). The decentralized government structure is of three major tiers, which comprises Federal, Regional, and the Local governments in which zonal (provincial) and wereda (district) as well as sub-city administrations are included.

The study data were collected from three tiers of government in order to liaise the trends and regulatory challenges of institutions from macro to micro levels. Hence, three major regions namely Oromia regional state, Southern Nations, Nationalities and People's Regional State (SNNPR) and Amhara regional state as well as Addis Ababa City administration were purposively selected to represent most of the geographic, climatic and demographic contexts of the country. In terms of population, these three regions and Addis Ababa city account for more than $80 \%$ per cent of the entire national population (CSA, 2013). Therefore, the following map illustrates these regions and zones selected for data generation. 


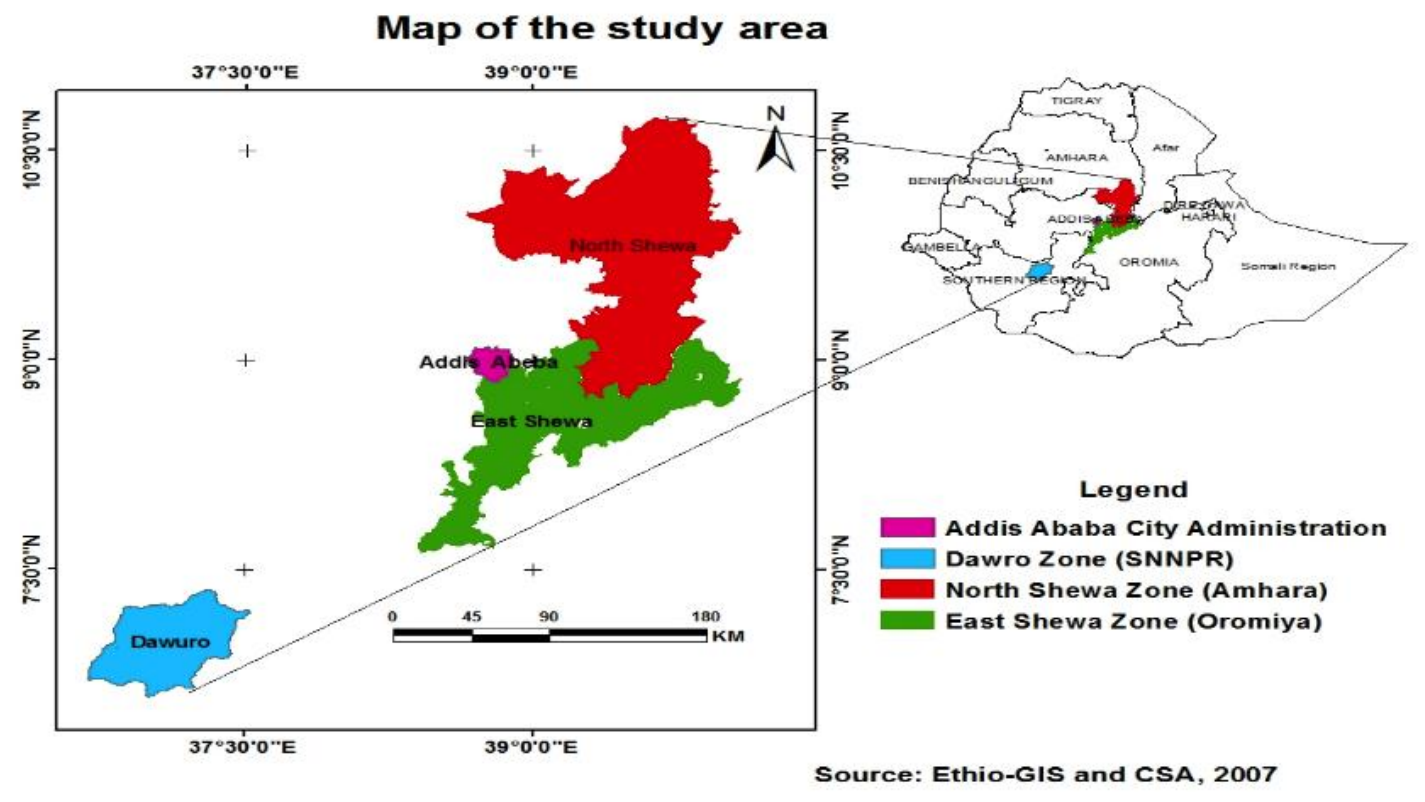

Figure 1. Location of the study areas

\subsection{Methods}

The study applied a multilevel analysis of institutions from the center to the local levels in order to see the trends and challenges of regulatory performances at each tier. Qualitative methodology was employed to generate in-depth information from key policy personnel and implementers across layers of government whereas review and analysis of relevant policy and legal documents, both at federal and regional levels, was conducted to identify trends, challenges policy and legal gaps.

\subsection{Site selection}

Due to the complex nature of environmental issues, cases were purposively selected from regions and federal institutions to incorporate different ecological and socio-economic contexts. This was to include pastoral, agrarian, resource conflict, industrial center and institutional concentration contexts. Following these contextual considerations, weredas (districts) and sub-city administrations were selected for data generation.

\subsection{Type and Sources of Data}

Primary data were collected from policy makers, experts, local level implementers, and communities through Key Informant Interviews (KIIs) and Focus Group Discussions (FGDs). To this end, twelve KIIs from federal ministries and relevant environmental institutions were interviewed, which involved serving as well as retired ministers. Four senior officials from regional environmental agencies, eight zonal and wereda officials, and twelve community development agents and local administrators were included in the KIIs. Similarly, a total of twelve community FGDs were conducted. Thus, there were a total of twenty-four KIIs and twelve FGDs contacted for this particular study. Secondary data was collected from federal and regional institutions, including rigorous review of relevant legal and policy documents. 


\section{Results and Discussion}

The following section highlights the trends of institutional development in recent Ethiopia with a focus at national level and the formation and expansion of environmental institutions at regional and local levels. The regulatory performances of institutions, challenges they face, and gaps and overlaps among these institutions at federal level are also briefly discussed. Finally, the trends of institutionalization across regions along with the prevailing inconsistencies in terms of nomenclature, autonomy, and status has also been analyzed while emphasizing on the outstanding challenges they currently face in discharging their regulatory mandates.

\subsection{Overview of the Recent Trends of Environmental Intuitions in Ethiopia}

Even though there were some rudimentary attempts of responses after the brief period of Italian occupation, environmental responses in Ethiopia noticeably begun during the monarchial period in 1960s following the severe effects of the great Ethiopian famine which claimed the lives of many citizens in the northern provinces (Dessaleng, 2001). With the support of multilateral donor agencies, there were attempts to carry out soil conservation measures in drought affected areas. There were also forest protection measures undertaken by the monarchial government which managed to institute the first state forestry department and moved further by setting up national parks for protection of plant and wildlife diversity, which laid a solid foundation for the current mosaic structure of Ethiopian protected area system (Steelmaker, 2007). After the downfall of the monarchial regime in 1974, the military Marxist government (Dergue) maintained the institutional and legal frameworks of forestry and soil conservation (Dessaleng, 2001). While dismantling a number of other institutional setups and policies of the past regime, it maintained the existing national park system, and reinforced the top down approach of governance (Stellmacher, 2007). Even though there were some regulatory reforms that repealed the forestry regulation of the monarchial regime (Negarit Gazeta, 1980) consistent with the momentous land reform of 1975 that transferred land ownership from the clergy and nobility to the farmers (Negarit Gazeta, 1975), the institutional setup of the wildlife and forestry did see insignificant changes. The previous Ethiopian wildlife organization, which had a mandate of governing parks and forest resources, was also maintained during the military era except slight changes in its nomenclature (Stellmacher, 2007).

During these two regimes, environment was merely synonymous with land based resources and the traditional trajectory of environmental institutions over the two regimes stayed more or less similar. As noted by a senior key informant, lack of broad environmental thought during the entire era of the monarchy and the Dergue has limited institutional setup to stay under Ministry of Agriculture (MoA). Therefore, there was no significant change in terms of institutional set up and policy making until early 1990s.

With the political change that ousted the Marxist regime in 1991, Ethiopia had experienced many political and economic reforms including changes in environment sector. The Ethiopian People's Revolutionary Democratic Front (EPRDF) led government has taken significant steps in formulating comprehensive policies and legal frameworks, which in turn were 
followed by waves of institutional formations and reformations resulted in the establishment of full-fledged environmental organs both at federal and regional levels. In general, while environmental responses in the western world were triggered by the effects of industrial pollution in 1960s (Jordan, 2005), rudimentary responses begun in Ethiopia in the same period due to soil degradation other than pollution, being limited to the conservation of land based resources.

\subsection{The First Wave of Institutionalization of Environmental Mandates}

MoA has long been the powerhouse of Ethiopia's environmental responses. The wildlife and forest governance as well as soil and water conservation activities were housed under MoA since the monarchy (Bekele, 2008) because environmental resources were seen from their contribution to agriculture and emphasis was only on soil and vegetation (Dessalegn, 2001). Thus, institutionalization and governance of these resources was highly unlikely to detach from MoA. During the period of political transition (1991-1995), the government undertook the first courageous measure to setup an independent Ministry of Natural Resources and Environmental Protection (MoNREP) in 1993, which can be labelled as the first wave of institutional response in environment sector. The ministry was meant to bring environmental affairs into a single visible institutional setup. According to the qualitative extracts, it was established by separation of natural resource related mandates from the MoA inclusive of broader environmental issues such as pollution control, climate change mitigation and adaptation. However, the brand new ministry, being a fresh phenomenon in the policy landscape of Ethiopia's environment sector did not stay long and suffered a merger back in to the old repository in about two years' time.

According to the senior officials, there were two reasons for merger of the short-lived ministry. First, the political orientations of the officials and experts under the ministry were found to be incongruent with that of the government which was readying itself to undertake massive soil conservation measures through public mobilization. The tendency within the ministry was expert-driven approach of conservation, which was not in harmony with the urgency that was posed by the recurrent droughts and resulting food deficit in the country. Second, there was a fierce antagonism from the old bureaucracy within the agriculture sector, who believed that governance of natural resource should have always stayed there, hence, the pressure from MoA coupled with the observed lack of fitness of the new ministry's personnel into the political views of the transitional government led to the fast merger of the ministry. Despite its fast merger, it can be noted that the country's commitment to set up the first independent ministry can be regarded as an attempt to line up in to the globally emerging paradigm of sustainable development and the Rio summit decisions to which Ethiopia was a party. As the literature suggests, this was the period that gave significant impetus for proliferation of environmental institutions on the aftermath of the long standing skepticism of third world countries over the sustainability paradigm that it could impede their economic development (Park et al., 2008; Ravnborg et al., 2013)). It was also evident that since the Brundtland Report of 1987 to Rio summit and a decade after the summit, there were over forty countries which prepared and approved environmental regulations with concurrent formation of relevant environmental institutions (Barrow, 2005; Ravnborg et al., 2013). 


\subsection{The Second Wave of Institutionalization}

As the reversal of the first wave of institutionalization and the quick merger of the new environmental ministry did not win acceptance from both donors and domestic environmentalists which attracted fierce criticism, the need to have another form of environmental regulatory organ was strongly pushed forward. In effect, Environmental Protection Agency (EPA) was established by Proclamation no. 9/1995. The EPA, hence, facilitated the formulation of the first and historic environmental policy of 1997 and its regulatory roles were further consolidated with the enactment of some key environmental laws including Environmental Impact Assessment (EIA) law (Mellese and Mesfin, 2008; Tsion, 2008; Ruffies et al., 2010).

Despite its re-establishment by proclamation 295/2002(Negarit Gazeta, 2002), which was an attempt to further strengthen its functions, its performance has got a lot of criticisms. Evidences indicate that its regulatory accomplishments in maintaining compliance were extremely poor. The major criticism arises from the lazes-fare practice of the implementation of the EIA proclamation (Mellese and Mesfin, 2008; Tsion, 2008; Ruffies et al., 2010; Adugna, 2016). Besides being poorly resourced, it lacked adequate statutory power to exercise effective control over government projects. Since many of the line ministries, which initiate the projects had more hierarchical power than the EPA, it was unable to exercise EIA rules on state sponsored projects (Mellese and Mesfin, 2008). Both qualitative extracts and empirical evidences have indicated that the negligence prevailed to tolerate some of the most polluting industries in Addis Ababa was so harmful. Tanneries and textile factories in some of the major cities including Addis Ababa, have long been causing air and water pollution to unprecedented level. While the effect of the unregulated effluent discharge has ever been worse, the record of EPA in deterring these factories was very poor (Ruffies et al., 2010; Mulugeta, 2012).

In the course of persistent institutional change, Proclamation no. 295/2002 provided for not only the re-establishment of EPA, but also created a platform for establishment of broader environmental organs both at federal and regional levels. Hence, formation of environmental council of higher profile and environmental units at sectoral levels of the federal government was undertaken coupled with establishment of regional environmental agencies (Negarit Gazeta, 2002) ${ }^{1}$. With this proclamation, the role and influence of EPA seemed to have been enhanced to the level that brought about advancement in environmental response at policy level and resulted in formulation of the Climate Resilient Green Economy (CRGE) strategy as well as the first Growth and Transformation Plan (GTP I) which unequivocally included environmental protection as a cross cutting development agenda (MoFED, 2010). However, as noted by a senior key informant, the poor awareness of environment was still pervasive among policy makers themselves which posed a challenge to mainstreaming environmental targets in to sectoral plans.

\footnotetext{
${ }^{1}$ Negarit Gazeta is an official Gazette (newspaper) of Ethiopian government in which laws and proclamations are published.
} 
The implementation of the strategy was also highly challenged with failure of some ministries to set up internal environmental units or making them idle even if they organized the units. The establishment of similar arrangements and practical implementation at the regions was also highly challenged. In this regard, a serving state minister noted that the institutional setup in the regions has been characterized by lack of uniformity and consistency with the national environmental policy goals. While the influence of agricultural sector on environment sector has begun to subside at federal level, the reality in the regions was still the same as environmental departments were locked for years under bureau of agriculture. Even though there were clear legal frameworks that provided for adequate and capable environmental institutions, the stature of institutional setup was far from strong [KII April, 2018].

\subsection{The Third Wave of Environmental Institutions}

With the growing role and raising voice of Ethiopia at international fora of climate politics, formulation of CRGE strategy was carried out in a manner that brought environmental thoughts to the next level (FDRE, 2011). A year before the formulation of the Climate Resilient Green Economy strategy(CRGE), the country introduced its first midterm plan (GTP 1) and this laid basis for planned response of environmental issues across sectors which considered environmental protection and climate change as cross cutting issues (Ministry of Finance and Economic Development [MoFED], 2010). The green development perspective was largely hailed by the policy elites and the need to carry out strong adaptation measures was seen as pivotal for agricultural growth that has often been vulnerable to climate induced shocks (Federal Democratic Republic of Ethiopia [FDRE], 2011). With the need to foster the country's vision of economic prosperity, on one hand and to resolve the weak regulatory capacity of EPA in relation to its lower hierarchical profile in the face of the muscular line ministries, on the other hand triggered the establishment of a full-fledged Ministry of Environment (MoE) for the second time in 2013 (Negarit Gazeta, 2013). After two decades, the country undertook similar measure to setup the ministry once again but with broader and clearer view of environmental understanding than the one before. MoE was established in 2013 to replace EPA, and it was again reestablished as Ministry of Environment, Forest and Climate Change (MoEFCC) in 2015 with mandates that comprise regulatory and development roles. Hence, the ministry has got broader role than ever before with all pertinent environmental mandates included in its role description (Negarit Gazeta, 2015). Despite the ongoing controversy of governance of forest related resources, which has long been oscillating in and around MoA, the new ministry seized the mandate of forest governance in full terms.

\subsection{Gaps and Overlaps in Institutional Roles at Federal Level}

All of the senior policy personnel contend that the tradition of role confusion in demarcation of power among the federal institutions has long been interruptive for environmental policy implementation in Ethiopia. In this regard, the case in point is related to the governance of forest resource. With the historical tradition that favoured $M o A$ to be the home of forest governance in nexus to agricultural expansion, the current governance of forestry aspect of 
resources has been scattered among five different institutions for different reasons (Table 1).

Table 1. Duplication of roles over forest resource governance

\begin{tabular}{|c|c|c|c|c|}
\hline Institution & Policy focus & Governance role & $\begin{array}{l}\text { Institutional } \\
\text { motive }\end{array}$ & Drivers \\
\hline $\begin{array}{lr}\text { Ministry } & \text { of } \\
\text { Agriculture } & \text { and } \\
\text { Nature Resource } & \end{array}$ & $\begin{array}{l}\text { Soil fertility \& } \\
\text { agroforestry }\end{array}$ & $\begin{array}{l}\text { Natural resource } \\
\text { rehabilitation }\end{array}$ & $\begin{array}{l}\text { Enhancing } \\
\text { productivity }\end{array}$ & $\begin{array}{l}\text { Agricultural } \\
\text { intensification tradition }\end{array}$ \\
\hline $\begin{array}{l}\text { Ministry of Culture } \\
\text { and Tourism }\end{array}$ & $\begin{array}{l}\text { Developing } \\
\text { tourist } \\
\text { destinations }\end{array}$ & $\begin{array}{l}\text { Governs federal } \\
\text { parks }\end{array}$ & $\begin{array}{l}\text { Revenue } \\
\text { generation }\end{array}$ & $\begin{array}{l}\text { Colonial tradition of } \\
\text { game hunting; frontier } \\
\text { economy paradigm }\end{array}$ \\
\hline $\begin{array}{l}\text { Ethiopian Wildlife } \\
\text { Conservation } \\
\text { Authority }\end{array}$ & $\begin{array}{l}\text { Wildlife } \\
\text { Protection }\end{array}$ & $\begin{array}{l}\text { Protection of } \\
\text { parks }\end{array}$ & $\begin{array}{l}\text { Conservation } \\
\text { of wild life }\end{array}$ & $\begin{array}{l}\text { Fortress model of } \\
\text { conservation }\end{array}$ \\
\hline Biodiversity Institute & $\begin{array}{l}\text { Biodiversity } \\
\text { Protection }\end{array}$ & $\begin{array}{l}\text { Research and } \\
\text { genetic } \\
\text { maintenance }\end{array}$ & $\begin{array}{l}\text { Genetic } \\
\text { preservation }\end{array}$ & $\begin{array}{l}\text { Genetic preservation; } \\
\text { response to the global } \\
\text { treaty of biodiversity }\end{array}$ \\
\hline $\begin{array}{l}\text { Ministry of } \\
\text { Environment, Forest } \\
\text { and Climate Change }\end{array}$ & $\begin{array}{l}\text { Environmental } \\
\text { protection }\end{array}$ & Regulatory body & $\begin{array}{l}\text { Protecting } \\
\text { forest biota }\end{array}$ & $\begin{array}{l}\text { Sustainable development } \\
\text { Paradigm }\end{array}$ \\
\hline
\end{tabular}

Source: Synthesized from qualitative data (2018).

Even if the governance of forest resources has recently been brought to the MoEFCC, there are traditional tendencies and misalignments among institutions in forest and wildlife governance. The qualitative study indicated that some element of forest of governance still exists at ministry of agriculture in the guise of 'Natural Resource', and the Ethiopian Wildlife Conservation Authority (EWCA) is also engaged in management of national parks where the forest resource is the habitat of the wildlife which is so difficult to detach one from the other (Damtie, 2010). While MoEFCC is fully responsible for forest resource development and governance, the EWCA is affiliated to the Ministry of Culture and Tourism (MoCT) (Damtie, 2010; EWCA 2016).

The vertical and horizontal integration of these institutions around forest based resource governance lacks clarity and logical connection. Since the Monarchy, EWCA had long been in and around the ministry of agriculture until its separation as an authority in 2008 (EWCA 2016), which again was annexed to the MoCT. The archival documents have shown that the authority was once absurdly affiliated to the national Biodiversity institute (Proc.No.120/1998), which in turn was instituted under the Agricultural Research organization of the MoA. According to the official from EWCA, its affiliation in to the institute had no single justification and brought back to the MoA only a year after its annexation by another proclamation (167/1999). Since then, the Key informant noted that there was a continued effort to elevate its status and hence the current EWCA was established in 2008 (Negarit Gazeta, 2008). The same official further noted that the process for establishment of independent EWCA was under serious dispute from MoA personnel. 
However, it was again affiliated to another remotely located ministry (MoCT) by proc.no.916/2015, whose roles were about development of culture, art, and tourism [KII Addis Ababa, June 2018].

Apart from the observed misalignment of the EWCA with the MoCT, role confusions are still prevalent between the MoEFCC and MoA. In the role description of MoA, according to the Proclamation No. 916. $/ 2015$ (MoEFCC 2014), there is still a residual sort of forestry governance that was expressed in terms of conservation of 'natural resource'. On the other hand, the MoEFCC has already been granted with broad forestry development mandate (Negarit Gazeta, 2015, 50). Even though forestry related mandate has been legally transferred to MoEFCC, the practical engagement of the MoA in forest development is massive. To this end, field evidences indicated that Ministry of Agriculture and Natural Resources (MoANR) is currently a real implementer of natural resource conservation more than anyone else. Explaining the significance of its practical engagement and justifying why the ministry should retain the forestry related activities, the former minister of agriculture argued as follows:

Ministry of Agriculture has long been endowed with huge grass root structure to mobilize the rural people. No other ministry has such a local capacity to closely work with the farming households. Even though forest related mandates were given to MoEFCC, it would not be able to mobilize people as it lacks strong grass root institution. If you scatter conservation works through different offices, you still scatter the work force at local level. In terms of CRGE, the vast work still lies under MoANR. However, to contain some aspects of environmental issues other than natural resource, and to have a focal body to the United Nations Framework Convention on Climate Change(UNFCC), establishment of MoEFCC was an imperative [KII Addis Ababa, June 2018].

From the above extract, it can be noted that regardless of the seizure of forest resource governance by the MoEFCC, which severely suffers from lack of capable local representative institutional setup, development and conservation of forests has been practically undertaken by the MoANR. Hence, the argument is that despite the law granting the mandate to the MoEFCC, MoANR is a de facto institution, which still maintains the practical aspect of afforestation activities. The point is, there is an ongoing confusion in terms of both legislation and practice particularly in relation to forest and natural resource governance. There is still lack of harmony as to who should do what and why, both in legislative documents and practical undertakings. Moreover, since the country is prone to recurrent droughts that often result in famine, the overwhelming focus of policy makers is towards agricultural development driven by fears that rigorous environmental regulations could affect the effort towards food production. Therefore, there is an implicit tendency of policy makers that forest governance should be the task of agriculture sector.

In spite of the above argument, a key informant from environment sector contends that since the legal mandate of natural resource development has already been transferred to the MoEFCC, there was no need for MoANR to engage in natural resource conservation. In a nutshell, the redundancy of efforts, confusion of roles, lack of coordination at local levels, 
and perceptual fallacies among senior policy makers themselves, as revealed in this study with regard to the forest and wildlife aspect of natural resource governance has been intense and of course invites confusion both at policy and implementing grounds.

\subsection{Trends and Regulatory Challenges of Regional and Local Environmental Institutions}

\subsubsection{Trends of Institutionalization at Regions}

Regional environmental organs epitomize another essential level of environmental institutions in Ethiopia, which were stipulated to be established across the regions in 2002(McKee, 2007). Following the 2002 proclamation that provided for establishment of the federal environmental organs including EPA and codified the establishment of independent regional environmental organs (Negarit Gazeta, 2002), there have been continuous re-establishments of the regional equivalent of the federal EPA that witnessed a chain of ups and downs with regard to nomenclature, autonomy, and statutory visibility (Damtie and Salamon, 2012). Before the establishment of the MoE, regional governments had undertaken their respective measures to form environmental institutions with varying degree of uniformity to the federal arrangement. Hence, there were continuous changes in some of the major regional states throughout a decade characterized by unnecessary amalgamation of environmental mandate with other executive functions (Tsion, 2008).

As noted by Melese and Mesfin (2008), lack of consistency in defining the regulatory mandates of regional EPAs, and blending them with land administration has been a characteristic feature of regional arrangements which have negatively affected the overall policy performance across regions. Empirical studies also indicate that the fast changes have caused regulatory instability and lack of institutional memory. In those blended institutions, the non-environmental blends were given overwhelming executive support while the environmental blend was given delicate attention. Similar arrangements down to local tiers have even suffered more confusion, lack of clarity and support (Damtie and Salamon, 2012). In this regard, a senior official from environment sector has noted:

The regulatory role of EPA was unpopular since there was little understanding of the necessary balance between environmental sustainability and economic development. Environmental protection, at its early times of EPA formation, was seen as something detrimental to the country's economic development, being exercised as result of external pressure. Even though there were quick responses from regions to form regional focal offices, it was not based on the real interest and knowledge to setup such a regulatory body that plays an actual deterring role over the possible harms due to development projects. That was why every region was blending the environmental protection aspect either in to land administration or agricultural department while refusing to give it an independent and elite status [KII Addis Ababa, April 2018].

However, the recent setup of regional environmental institutions since the formation of the third generation environmental institution at federal level, has shown some improvements as indicated in Table 2. 
Table 2. The current setup of regional environmental institutions

\begin{tabular}{|l|l|l|}
\hline Regional state & Non-environmental blend & Status \\
\hline Amhara & - & Cabinet member \\
\hline Tigray & Rural land Administration & Below Cabinet status \\
\hline Oromia & - & Cabinet member \\
\hline Southern Regional State(SRS) & - & Below Cabinet status \\
\hline Benshgul Gumuz & Land administration & Cabinet member \\
\hline Gambella & - & Cabinet member \\
\hline Afar & Rural land Administration & Below Cabinet status \\
\hline Somali & Mines and Energy & Below Cabinet status \\
\hline Harari & - & Below Cabinet status \\
\hline Addis Ababa & - & Below Cabinet status \\
\hline Dire Dawa & - & Below Cabinet status \\
\hline
\end{tabular}

Source: (MoEFCC, 2018)

As can be seen from Table 2, among eleven regional institutions, three of them are blended with land administration and use, while that of Somali region is blended with mines and energy, which is entirely different arrangement from the rest. The number of regional institutions with purely environmental mandate has shown significant increase from that of the EPA era as discussed earlier. Some of these regions even tried to follow similar nomenclature to the federal ministry inclusive of 'environment, forest and climate change'. Thus, progress has been made in terms of creating independent environmental institutions with purely environmental mandates. However, there are still some formidable challenges in the current regional arrangements.

\subsubsection{Regulatory Challenges of Regional and Local Institutions}

As highlighted in above section, the changes in institutionalization have been chaotic and interruptive. The study revealed that there were three major pitfalls and regulatory challenges commonly encountered by regional and local institutions.

\section{A. Challenges in relation to autonomy and decision making}

The former EPA's poor performance in enforcing the EIA law was partly related to its lower status than the ministries that initiate government sponsored projects as these were members of the council of ministers with more power than the EPA (Damtie and Salamon, 2012). Similarly, seven out of eleven regional institutions, regardless of their nomenclature and composition of tasks, are below cabinet status with less power than the other bureaus. In this regard, an official from SNNPR EPA has noted that because of its lower status than other regional bureaus, the regional EPA has been challenged to enforce environmental laws including EIA. Those at cabinet status often disregard the regulatory demands of EPA and implementation of the rules is dependent on the willingness of the bureau heads who are members of the regional executive council.

B. Weak executive support and lack of uniformity 


\section{Mll Macrothink}

Environmental Management and Sustainable Development

ISSN 2164-7682 2019, Vol. 8, No. 2

Weak support and lack of uniform arrangements down to the zonal and wereda levels is another challenge. As key informant responses across the regions have asserted, the sector receives the lowest human, material and financial support in comparison to other sectors. According to the interview extract from Amhara region, even though the structure at region level is at cabinet status with purely environmental mandates; the reality down to the zonal and wereda levels is totally opposite. Thus, the zonal arrangement has completely eliminated the environmental branch and structured as "zonal department of Rural Land Administration and Use" under which "Environmental Sustainability process" was organized as a unit being run by finger counting experts. The same replica of this zonal arrangement prevails at wereda level while the degree of lack of support increases from zone down to wereda. Hence, the commitment demonstrated at regional level could not be repeated at lower levels where much of the regulatory and development activities take place.

By the same token, qualitative evidences in Southern Regional State have shown that the local level arrangements have followed the regional arrangement of EPA. However, besides marginal support in terms of budget and facility, the deployment of office heads in some of the zonal and wereda administrative structures has not been meritocratic. As noted by a regional official, the position of EPA head in some of the administrative divisions was assumed by those who have either lost their previous jobs due to incompetence, or it is considered to be a position to land someone a new comer with zero experience. Hence, incompetent individuals were appointed in some of the lower administrative branches, which is indicative of weak attention given to the sector. It was also reported that the meager support to the wereda EPA offices has been detrimental to achieve their planned targets. One of the wereda EPA heads in SNNPRS narrated: "we are unable to carry out our regulatory roles due to lack of budget, office and field facilities. We are given virtually the least support as compared to other line offices" [Wereda level KII, May 2017]. Similarly, EPA representatives and FGD members in sub cities of Addis Ababa city have also reiterated that the regulatory performance of EPA has been seriously constrained by poor executive support.

C. Overlaps in roles and mandates

Another problem is related to the role confusion with the bureau of agriculture. The influence of agriculture sector on the environment sector is still immense. Because of its historical legacy, the mandate of forest governance has got confusion between two institutions. Similar to the federal level, forest governance has fully been transferred to environment sector in the regions. However, the agriculture sector still carries out forest related function without any adequate legal support. As noted by the senior official from Amhara region,

The agriculture sector still maintains forest development activities while the environment sector has been given clear legal mandate. They are still conducting afforestation activities and the Natural Resource department within the sector down to zonal and wereda levels is often confused to whom to report. They are currently reporting to dual lines of command, both to the agriculture office and to the environment sector. The reason for this confusion is a race for resources. There is a huge flow of resources from foreign sources and that is why the battle to retain the forest mandate is still intense [KII Bahir Dar, Oct. 2017]. 
Similarly, the key informant from SNNPR EPA noted:

The resources and benefits from forest support projects have long been there and widely utilized within the old sector. Hence, nobody wants the new sector to overtake what was thought to have been the old sector's private endowment. This is the main source of antagonism with the newly emerging sector of environment and allocation of environmental mandates has been mostly influenced by the parochial interest from the old sector [KII Hawassa, January 2018].

Field observation in three regions has also confirmed that the practice of forest development is being carried out by the local agricultural or its equivalent office in pastoral areas whereas environment sector has rarely been engaged in coordination of this particular activity. In the case of Addis Ababa city, the city level EPA has relatively good resource support, expertise and infrastructure to carry out its regulatory mandates. However, the reality down the Sub-city and wereda levels is totally different. There is an office head at sub-city level being poorly resourced and weakly empowered to undertake regulatory measures. At wereda level, a single expert was employed under the wereda administration office. During the field data collection, the designated experts of two weredas have noted that they lacked clarity on what they were supposed to do; they have no clear job description, execution plan and resources [Source: Expert interview, January 2018]. As the foregoing discussions made it evident that the dispersion of regional institutional setup poses a formidable challenge to enforce national environmental laws and achieve common targets. Lack of similarity has negative effect from the perspective of the KII from federal MoEFCC. The KII noted that lack of similarity and blended nature of the institutions with non-environmental mandates has made it difficult to provide necessary support to the regions. The regional offices are often confused to directly report their performances to MoEFCC since there are dual lines of command, which makes it difficult to provide clear support for regions. In a nutshell, evidences suggest that the current arrangement, even though progresses have been made since the end of EPA era, is posing critical challenge to the smooth implementation and harmonization of the environmental policy across the regions.

\section{Conclusion}

The study has found out that environmental institutional development in Ethiopia has experienced a considerable lag until the mid-1990s. Since then, with the formulation of coherent environmental policy, Ethiopia experienced the three waves of proliferation of environmental institutions. However, the regulatory performance of these institutions has been very poor and challenged by a host of factors.

First, the recurrent droughts and resulting food insecurity that defined the face of the country over the last fifty years has shifted the entire focus towards agricultural production and use of resources to boost it. Second, the frontier economy perspective has been highly dominant and resource depleting economic growth was given due priority over environmental protection, ultimately influencing the definition of "Environment" to be limited to and synonymous with land based or agricultural resources. Third, environmental institutions have been victims of long standing resource race that flows from foreign sources in relation to forest development. 


\section{Macrothink}

The race towards retaining sustained control over the use of foreign finance, overseas training, and project based amenities in relation to forestry sub-sector has been causing fierce antagonism between the old and the new sector and this has had an enduring effect on the autonomy, role clarity and stability of environmental institutions. In most cases, policies and decisions that could favor environmental institutions were unfavorably influenced by officials and experts from agriculture sector in a way that maintains their long standing dominance over forest resources driven by sectoral parochialism. Thus, despite the recent development with the changing narrative of environmental policy and proliferation of environmental institutions across the three waves, the influence of agriculture sector is still prevalent at all levels, severely affecting the regulatory capacity of environmental institutions.

Therefore, it is suggested that revision of environmental mandates across all tiers should be pursued based on clear understanding of the virtues of having a strong and independent environmental regulatory body. Since the current diversity of environmental institutions across regions puts a formidable challenge to execute nationally agreed targets; the status and autonomy of regional institutions should be elevated to a similar level. Moreover, there should be a commitment to free them from conflict of interest which arises from incompatible amalgamation; and provide necessary support through changing the erroneous perception that environmental regulations would stifle economic growth.

\section{Acknowledgements}

The authors are thankful to the Christensen Fund for the grant support.

\section{Conflicts of Interest}

The authors declare no conflict of interest.

\section{References}

Adugna, F. (2016). Environmental impact assessment in Ethiopia: A general review of history, transformation and challenges hindering full implementation. Journal of Environment and Earth Science, 6(1), 1-9

Barrow, C. J. (2005). Environmental management and development: Routledge Perspectives on Development. New York, USA.

Bekele, M. (2008). Ethiopian environmental policies, strategies and programs. Digest of Ethiopia's national policies, strategies and programs. Addis Ababa: Forum for Social Studies, 337-70.

Berkes, F. (2010). Devolution of environment and resources governance: Trends and future. Environmental Conservation, 37(4), 489-500. https://doi.org/10.1017/S037689291000072X

Bhattarai, M., \& Hammig, M. (2001). Institutions and the environmental Kuznets curve for deforestation: A cross-country Analysis for Latin America, Africa and Asia. World Development, 29(6), 995-10101. https://doi.org/10.1016/S0305-750X (01)00019-5

Birhanu, A. (2014). Environmental degradation and management in Ethiopian highlands: 
Review of lessons learned. International Journal of Environmental Protection and Policy, 2(1), 24-34. https://doi.org/10.11648/j.ijepp.20140201.14

Cent, J., Grodzińska-Jurczak, M., \& Pietrzyk-Kaszyńska, A. (2014). Emerging multilevel environmental governance: A case of public participation in Poland. Journal for Nature Conservation, 22(2), 93-102. https://doi.org/10.1016/j.jnc.2013.09.005

Central Intelligence Agency. (2018). Ethiopia. In The World factbook. Retrieved from https// WWW.cia.gov/library/publications/the-world-factbook/geos/et.html

Central Statistical Authority (CSA). (2007). Statistical Abstract. Addis Ababa, Ethiopia.

Emelie, C., \& Ekbom, A. (2013). Ethiopia environmental and climate change policy brief. SIDA's Helpdesk for Environment and Climate Change.

Environmental Protection Authority (EPA). (2012). National Report of Ethiopia. The United Nations Conference on Sustainable Development (Rio+ 20), Federal Democratic Republic of Ethiopia, EPA, Addis Ababa.

Ethiopian Wildlife Conservation Authority (EWCA). (2016). Background History of EWCA (unpublished), Addis Ababa, Ethiopia.

Evans, J. (2012). Environmental governance. Routledge.

https://doi.org/10.4324/9780203155677

Federal Democratic Republic of Ethiopia (FDRE). (1995). Constitution of the federal democratic republic of Ethiopia. Addis Ababa.

Federal Democratic Republic of Ethiopia (FDRE). (2011). The climate resilient green economy (CRGE) Strategy. Addis Ababa, Ethiopia.

Hsu, A., Esty, D. C., de Sherbinin, A., Levy, M. A., et al. (2016). 2016 Environmental performance index: Global Metrics for the Environment. New Heaven, CT: Yale Center for Environmental Law and Policy.

Hurni, H., Solomon, A., Amare B., Berhanu., D, Eva, L., Brigitte, P., Birru, Y., \& Gete, Z. (2010). Land degradation and sustainable land management in the highlands of Ethiopia. 187-207.

Janka, D, G. (2014). Remedies for environmental wrong-doings in Ethiopia. Mekelle ULJ, 2(1).

Jordan, A. (2005). Environmental policy in the European Union: Actors, institutions and processes. $2^{\text {nd }}$ (Ed.). Earth scan UK and USA.

Keeley, J., \& Ian, S. (2003). Understanding environmental policy processes: Cases from Africa, London: Earth scan.

Krueger, J., Aman, K. G., \& Inku, I. (2012). Environmental permitting in Ethiopia: No restraint on unstoppable growth? Haramaya Law Review, 1(1), 73-102. 


\section{Macrothink}

Environmental Management and Sustainable Development

ISSN 2164-7682 2019, Vol. 8, No. 2

McKee, J. (2007). Ethiopia: country environmental profile. EC Delegation, Addis Ababa, Ethiopia.

Mellese, D. (2010). Legal and institutional issues for environment in Ethiopia in 2008. Forum for Environment, Addis Ababa, Ethiopia.

Mellese, D., \& Kabada, S. (2012). The need for redesigning and redefining institutional roles for environmental governance in Ethiopia. MELCA-Ethiopia.

Mellese, D., \& Mesfine, B. (2008). Overview of environmental impact assessment in Ethiopia. gaps and challenges, MELCA Mahiber, Addis Ababa, Ethiopia.

Ministry of Environment and Natural Resources (MoENR). (1994). National conservation strategy of Ethiopia, 2, Addis Ababa.

Ministry of Environment, Forest and Climate Change (MoEFCC). (2017). List of regional environmental bureaus and their respective status (unpublished), Addis Ababa.

Ministry of Environment, Forest and Climate Change, (MoEFCC). (2014). National REDD+ strategy, National REDD+ secretariat, Addis Ababa Ethiopia.

Ministry of Environment, water and Natural Resources of Kenya. (2013). National Environmental Policy of Kenya, Nairobi.

Ministry of Finance and Economic Development (MoFED). (2010). Growth and transformation plan (GTP II), 2010/11-2014/15.Addis Ababa, Ethiopia.

Ministry of Finance and Economic Development (MoFED). (2014). Growth and transformation plan annual progress report for F.Y. 2012/13. Addis Ababa, Ethiopia.

Misginna, A. (1991). The history of the Ethiopian wildlife conservation organization. $\mathrm{PhD}$ dissertation, History Department, College of Social Sciences, Addis Ababa University, Ethiopia.

Mruma, R., O. (2005). Implementation of the national environment policy: a case of the local government authorities in Dar Es Salaam city of Tanzania, (MA thesis). Department of Public Administration and Organization Theory, University of Bergen.

Mulugeta, G. (2012). The Ethiopian environmental regime versus international standards: Policy, Legal, and Institutional Frameworks. Haramaya Law Review, 1(1), 43-72.

Negarit, G. (1975). Proclamation to provide for the public ownership of rural lands, no.31/1975. No.26.

Negarit, G. (1980). A proclamation to provide for the conservation and development of Forest and Wildlife Resources, No.192/1980, No.17.

Negarit, G. (2002). Proclamation to provide for establishment of environmental protection Organs, No.295/2002, No.7.

Negarit, G. (2008). Ethiopian wildlife development and conservation authority establishment 
proclamation no. 575/2008, No. 31 .

Negarit, G. (2013). Definition of powers and duties of the executive organs of the Federal Democratic Republic of Ethiopia (Amendment) Proclamation No.803/2013. No. 61.

Negarit, G. (2014). Ethiopian environment and forest research institute establishment Council of Ministers Regulation No.327/2014, No.5.

Negarit, G. (2015). Definition of powers and duties of the executive organs of the Federal Democratic Republic of Ethiopia Proclamation No. 916. /2015, No.12.

Organization for Economic Cooperation and Development (OECD). (2012). Greening development: Enhancing capacity for environmental management and governance, OECD Publishing, Paris.

Park, J., Conca., K \& Finger, M. (Eds.). (2008). The crisis of global environmental governance: Towards a new political economy of sustainability. Routledge, USA and Canada.

Rahmato. D. (2001). Environmental change and state policy in Ethiopia: lessons from past experience. Forum for Social Studies, Addis Ababa, Ethiopia

Ravnborg, H. M., Klocker, L. R., Jon Lausten, V., \& Funder, M. (2013). Environmental governance and development cooperation achievements and challenges: DIIS report 2013:15.

Reed, M. G., \& Bruyneel, S. (2010). Rescaling environmental governance, rethinking the state: A three dimensional review. Progress in Human Geography, 34(5), 646-653. https://doi.org/10.1177/0309132509354836

Rossouw, N., \& Wiseman, K. (2004). Learning from the implementation of environmental public policy instruments after the first ten years of democracy in South Africa. Impact Assessment and Project Appraisal, 22(2), 131-140.

https://doi.org/10.3152/147154604781766012

Ruffeis, D, Willibald, L, Seleshi, B., A., \& Eline, B. (2010). Evaluation of the environmental policy and impact assessment process in Ethiopia. Impact Assessment and Project Appraisal, 28(1), 29-40. https://doi.org/10.3152/146155110X488844

Stellmacher, T. (2007). The historical development of local forest governance in Ethiopia: From imperial times to the military regime of the Derg. Africa Spectrum, 42(3), 519-530.

Swedish Environmental Protection Agency (SEPA). (2012). The role of governance for improved environmental outcomes: Perspectives for developing countries and countries in transition. Stockholm, Sweden.

Tsion Y. (2008). Environmental impact assessment implementation and challenges. MELCA Mahiber in collaboration with Sheka Forest Alliance, Addis Ababa, Ethiopia.

Underdal, A. (2010). Complexity and challenges of long-term environmental governance. Global Environmental Change, 20(3), 386-393.

https://doi.org/10.1016/j.gloenvcha.2010.02.005 


\section{Macrothink}

Environmental Management and Sustainable Development

ISSN 2164-7682 2019, Vol. 8, No. 2

United Nations Economic Commission for Europe. (UNECE), Committee on Environmental Policy. (2007). Critical issues in implementation of environmental policies: from intentions to actions, overcoming bottlenecks. New York and Geneva.

United Nations International Children's Emergency Fund (UNICEF). (2006). Ethiopia Country Profile. [Online] Available:

https://www.unicef.org/ethiopia/ECO_Ethiopia_Country_Profile.pdf

Wolde, E. T. (2015). Economic growth and environmental degradation in Ethiopia: An environmental Kuznets curve analysis approach. Journal of Economics and International Finance, 7(4), 72-79. https://doi.org/10.5897/JEIF2015.0660

World Bank. (2008). Global monitoring report: MDGs and the environment-agenda for inclusive and sustainable development, World Bank, Washington, DC.

Young, O. R. (2002). Institutional dimensions of global environmental change. public administration and public policy. Vol. II- Institutional Dimensions of Global Environmental Change

Zeleke, G. (2010). A study on mountain externalities in Ethiopia. food and agricultural organization of the united nations: sustainable agriculture and rural development mountain policy project. Addis Ababa: Ethiopia.

\section{Copyright Disclaimer}

Copyright for this article is retained by the author(s), with first publication rights granted to the journal.

This is an open-access article distributed under the terms and conditions of the Creative Commons Attribution license (http://creativecommons.org/licenses/by/3.0/). 